\title{
Konsepsi Bentuk Negara Kesatuan Sebagai Klausul yang Tidak Dapat Dirubah dalam Konstitusi
}

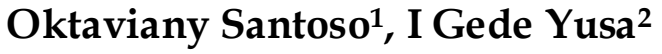

1Firma Hukum Irma, E-mail: tata.irmalawfirm@gmail.com

2Fakultas HukumUniversitas Udayana, E-mail: gedeyusa345@gmail.com

\begin{tabular}{l}
\hline Info Artikel \\
\hline Masuk:28 Januari 2021 \\
Diterima:25 September 2021 \\
Terbit:30 September 2021 \\
Keywords: \\
Constitution; Unamendable \\
Provision; Unitary State \\
\\
\\
DOI: \\
10.24843/JMHU.2021.v10.i03.p11 \\
Corresponding Author: \\
tata.irmalawfirm@gmail.com \\
Kata kunci: \\
Danstitusi; Klausul Yang Tidak \\
Diubah; Negara Kesatuan \\
Dantoso, \\
\end{tabular}

\begin{abstract}
The conception of the form of the Unitary State of Indonesian as an irreversible clause is regulated in the constitution to be precise "Artide 37 paragraph (5)", which result of the fourth amandment. The existence of this unchanged dause has resulted in the inharmonization of norms in relation the provision that the highest state institution has the authority to amend and enact the Basic Law. Furthermore, the problem also relates to the basis for consideration and the urgency of the existence of a clause that cannot be dhanged in the constitution. The purpose of writing/ research is to dtermine the existence of a dause that cannot be chnaged in the constitution (unamendable provision), as well as how it stands. The law normative research used in the study is based on statute approach, historical approach, conceptual approach. The conclusion research that the application of "Artide 37 paragraph (5)" has also been based on philosophical, sociohistorical and judical-normative considerations. Futhemore, the urgency of the existence of the Article has also been based on the concept of clear objectives and the need for regulation. Based on these matters, its existence is a form of supermacy that imposes restrictions on the state apparatus in making amendments to the 1945 Constitution of the Republic of Indonesia. This is shown to uphold the values, nature and objectives of the constitution it self.
\end{abstract}

\begin{tabular}{l}
\hline Abstrak \\
\hline Konsepsi bentuk Negara Kesatuan Indonesia sebagai klausul \\
yang tidak dapat dirubah diatur dalam konstitusi tepatnya \\
"pasal 37 ayat (5)", yang merupakan hasil amandemen keempat. \\
Keberadaan klausul yang tidak dirubah itu menimbulkan \\
inharmonisasi norma dalam keterkaitannya dengan ketentuan \\
bahwa Lembaga Tertinggi Negara, mempunyai mandat untuk \\
merubah dan mengkukuhkan Undang-Undang Dasar.Lebih \\
lanjut persoalan juga berkaitan dengan dasar pertimbangan dan \\
urgensitas dari diadakannya suatu klausul yang tidak dapat \\
dirubah dalam konstitusi. Tujuan penulisan ini untuk \\
mengetahui keberadaan klausul yang tidak dapat dirubah \\
didalam konstitusi, serta seberapa penting keberadaan klausul \\
tresebut. Penelitianhukum normatif digunakandalam penelitian \\
ini dengan didasarkan pada pendekatan peraturan perundang- \\
undangan, pendekatan sejarah, pendekatan konseptual. \\
Kesimpulan dalam penelitian ini adalah diterapkannya "Pasal 37 \\
ayat (5)" juga telah didasarkan dengan pertimbangan filosofis, \\
sosio-historis dan yuridis -normatif. Lebih lanjut urgensitas dari
\end{tabular}


keberadaan Pasal tersebut juga telah didasarkan pada konsep tujuan yang jelas dan perlunya pengaturan. Berdasar kepada hal-hal tersebut maka keberadaannya merupakan bentuk supremasi yang memberikan pembatasan kepada alat-alat kelengkapan negara dalam hal melakukan perubahan UUD NRI 1945. Hal ini ditunjukan untuk menegakkan nilai-nilai, hakikat dan tujuan konstitusi itu sendiri.

\section{Pendahuluan}

Konsepsi Negara Kesatuan Indonesia suatu negara yang dipondasikan atas hukum (rechstsaat) dan bukanlah negara bermodalkan kekuasaan belaka (machstaat). Meninjau "Pasal 1 ayat (3)" UUD NRI 1945 mendeklarasikan bahwa hukum menjadi dasar negara Indonesia. Keadaan tersebut memunculkan konsekuensi yuridis bahwa hukum merupakan dasar dalam setiap tanduk dalam berbangsa dan bernegara. ${ }^{1}$ Konsepsi sebagai sebuah negara hukum, Indonesia meletakan Pancasila menjadi filosofische grondslag atau falsafah bangsa dalam artian sebagai sumber hukum materiil bangsa Indonesia dan UUD NRI 1945 merupakan sumber hukum formal. Sepanjang perjalananya mengiringi kemerdekaan Indonesia sebanyak empat kali perubahan terhadap UUD NRI 1945 telah dilakukan.

Pada tahun 1999 dilakukan perubahan pertama kali, yang ditetapkan pada 19-10-1999, selanjutnya perubahan kedua terjadi 18-08-2000, dan pada tanggal 10 November 2001, untuk ketiga kalinya dilakukaan perubahaan.Kemudian perubahan keempat pada tanggal 10 Agustus 2002. Amandemen terhadap UUD NRI 1945 adalah suatu ikhtiar besar bangsa Indonesia dalam usaha menyempurnakan konstitusi, mengingat UUD NRI 1945 merupakan revolutie groundwet. Sri Soemantri menyatakan bahwa amandemen atau perubahaan konstitusi tidak hanya dimaknai dengan merubah isi dan bunyi ketentuan, namun juga menambahkan atau mengurangi pasal-pasal dalam UUD 1945. ${ }^{2}$ Hal ini suatu perubahan atau amandemen terhadapnya tidak dapat dilakukan begitu saja, namun harus mempertimbangkan beberapa hal sebelum menetapkan keputusan untuk melaksanakan perubahan atas konstitusi yaitu sebagai berikut :

a. Adakah keperluan mendesak yang membuat kita dihadapkan pada beberapa pilihan penting.

b. Seberapa kelayakan yang menitiberatkan pada keseimbangan dan keperluan mendesak dan kelayakan dari sebuah perubahan.

c. Ukuran perubahan pokok yakni perubahan yang didasarkan oleh suatu pertimbangan dari aspek seperti ekonomi, sosial dan budaya.

Hal ini menandai era konstitusionalisasi di Indonesia dengan adanya dinamika atas konstitusi Indonesia dalam hal ini UUD NRI 1945 yang mengalami perubahan

\footnotetext{
1 Jimly Asshiddiqie and M Ali Safa'at, "Hans Kelsen's Theory of Law," Secretariat General and Registrar of the Constitutional Court, Jakarta, 2006.

2 Martosoewignyo, Sri Soemantri. Procedures and sustems of constitutional changes in the torso of the 1945 Constitution: before and after the amendment of the 1945 Constitution. Alumni, 2006.
} 
sebanyak empat kali ${ }^{3}$ membawa banyak konsep-konsep perubahan fundamental yang menimbulkan pertanyaan hingga sampai saat ini. Antara lain mengenai pasal 37 ayat (5), pembahasan secara khusus dilakukan pada pasal khusus yang membicarakan tentang perubahaan UUD NRI 1945 dalam segi prosedur dan pembatasannya.

Prespektif sebenarnya telah ditentukan dalam mekanisme perubahaan atas UUD NRI 1945 seperti yang termaktub dalam Bab XVI Perubahan Undang-Undang Dasar. Hal yang perlu ditelisik yang pada pokoknya mengatur mengenai mekanisme terhadap perubahan justru menentukan adanya sebuah klausul yang melarang dilakukannya suatu perubahan terhadapnya. Dalam memahamai kontekstualisasi dari perubahan konstitusi tentu tidak dapat kita lepaskan dari Majelis Pemusyawaratan Rakyat (selanjutnya disebut MPR) yang memiliki mandat untuk mengubah dan menetapkan UUD NRI 1945 hal ini yang termaktub dalam "pasal 3 ayat (1) sehingga keberadaan pasal 37 ayat (5)" yang melarang perubahan terhadap konsep negara kesatuan dalam melaksanakan perubahan UUD NRI 1945 memunculkan inharmonisasi norma. Pernyataan tersebut merupakan bentuk pembatasaan untuk perubahaan Bentuk Negara Kesatuan Indonesia, bahwa untuk Bentuk Negara Kesatuan Indonesia di perubahan konstitusi sama sekali tidak dapat diubah, sehingga timbul pembatasan dan kepastian hukum terhadap perubahan konstitusi. ${ }^{4}$

Pembatasan terhadap perubahan Bentuk Negara Republik Indonesia memiliki aspek sejarah hal ini dapat dilihat dari ketentuan yang telah di susun, yaitu Kesepakatan Dasar perubahan UUD NRI 1945. Kesepakatan Dasar yang disusun oleh Panitia Ad Hoc I, ini berisi kesepakatan yang disetujui secara bersama-sama, hal- hal yang diatur dalam risalah-risalah rapat Panitia Ad Hoc I, antara lain:

1) Tidak adanya perubahaan dalam Preambule ;

2) Konsepsi negara kesatuan republik Indonesia harus dipertahankan;

3) Bentuk pemerintahan sistem presidensial semakin dipertegas;

4) Segala sesuatu yang bersifat normatif yang terdapat di dalam penjelasan UUD NRI 1945 dijadikan pasal-pasal (batang tubuh);

5) Adendum adalah alat yang digunakan untuk melakukan perubahan;

Pertanyaan harus mampu dijawab adalah berkaitan dengan dasar pertimbangan ditetapkan pasal yang melarang perubahan terhadap bentuk negara kesatuan dalam melakukan perubahaan UUD 1945. Sehingga perlu menelisik lebih lanjut mengenai pertimbangan apa yang melahirkan adanya unamendable provision dalam konstitusi dan urgensi dari ditetapkannya pasal tersebut yang melarang dilakukan perubahan bentuk negara kesatuan dalam melakukan perubahan UUD NRI 1945. Hal inilah yang menjadi dasar pentingnya dilakukan penelitian tentang konsepsi bentuk Negara Kesatuan sebagai klausul yang tidak dapat dirubah dalam konstitusi. Persoalan yang akan dikaji adalah dasar pertimbangan terdapatnya unamendable provision dalam konstitusi, serta

\footnotetext{
${ }^{3}$ I Gede Yusa and Bagus Hermanto, "Implementasi Green Constitution Di Indonesia: Jaminan Hak Konstitusional Pembangunan Lingkungan Hidup Berkelanjutan," Jurnal Konstitusi 15, no. 2 (September 18, 2018): 306-26, https://doi.org/10.31078/JK1524.

${ }^{4}$ Mardian Wibowo, "Menakar Konstitusionalitas Sebuah Kebijakan Hukum Terbuka Dalam Pengujian Undang-Undang," Jurnal Konstitusi 12, no. 2 (May 20, 2016): 196-216, https://doi.org/10.31078/JK1221.
} 
urgensi pembentukan pasal yang melarang dilakukan perubahan tentang bentuk negara kesatuan. ${ }^{5}$

Penelitian tentang unamendable provision sudah beberapa kali dilakukan Seperti penelitian sebelumnya Ivan Tjahjadi melakukan penelitian yang berjudul eksistensi larangan perubahan pasal tertentu dengan mekanisme perubahan konstitusi dan hubungannya dengan hakikat konstitusi. ${ }^{6}$ Ada pula penelitian Cipto Prayitno berjudul Pembatasan Peubahan Bentuk Negara Kesatuan dalam konstitusi dalam Prespektif Constituion Making. ${ }^{7}$ Pada Tahun 2018 ada juga penelitian yang dilakukan oleh Abdurrachman Satrio yang memiliki judul Klausul Larangan : Prespektif Identitas Konstitusi. ${ }^{8}$ Namun dengan banyak penelitian yang berkaitan, di dalam penelitian ini akan membahas permasalahan yang berbeda terutama tentang dasar pertimbangan dan seberapa pentingnya klausal yang tidak dapat dirubah dalam konstitusi yang berhubungan dengan bentuk negara kesatuan yang dianut Indonesia.

\section{Metode Penelitian}

Studi ini diklasifikasikan dalam penelitian hukum normatif, hal ini dikarenakan permasalahan hukum yang diteliti bertitik fokus pada problema norma yang muncul yang difokuskan pada bahan-bahan hukum yang terkait dan dilandasi pada hasil kepustakaan, dengan pendekatan undang-undang (statute approach), pendekatan konseptual (conceptual approach) dan pendekatan sejarah (historical approach) yang terkait dengan klausul yang tidak dapat dirubah (Unamendable Provision) dalam konstitusi. Teknik yang diterapkan dalam pengumpulan bahan hukum primer dan sekunder berupa teknik telaahan kepustakaan (study document). Dalam penerapan teknik telaahan kepustakaan itu didukung pula oleh teknik bola salju dengan menemukan bahan hukum sebanyak mungkin dari informasi awalnya sedikit sehingga bahan hukum yang diperoleh dapat menjadi lengkap dan seobyektif mungkin untuk selanjutnya dilakukan interprestasi, evaluasi serta dianalisis isinya (content analysis)

\footnotetext{
${ }^{5}$ Agus Salim, Agus Ngadino, and Vegitya Ramadhani Putri, “Keberadaan Klausul Yang Tidak Dapat Diubah (Unamendable Provision) Dalam Undang-Undang Dasar Negara Republik Indonesia Tahun 1945," March 18, 2018.

6 Ivan Tjahjadi, "Eksistensi Pasal 37 Ayat (5) Undang-Undang Dasar 1945 Sebagai Larangan Perubahan Pasal Tertentu Dalam Mekanisme Perubahan Konstitusi Dan Hubungannya Dengan Hakikat Konstitusi," 2018, repository.unpar.ac.id/handle/123456789/7414.

${ }^{7}$ Cipto Prayitno, "Pembatasan Perubahan Bentuk Negara Kesatuan Dalam Undang-Undang Dasar 1945 Dalam Perspektif Constitution Making," Jurnal Konstitusi 15, no. 4 (January 15, 2019): 732-51, https://doi.org/10.31078/JK1543.

8 Abdurrachman Satrio, "Klausul Larangan Mengubah Bentuk Negara Kesatuan Republik Indonesia Dalam Undang-Undang Dasar 1945: Perspektif Identitas Konstitusi," 2018, http://repository.unpad.ac.id/frontdoor/index/index/docld/1811.
} 


\section{Hasil dan Pembahasan}

\subsection{Dasar Pertimbangan Terdapatnya Klausul Yang Tidak Dapat Dirubah Dalam Konstitusi}

Bentuk, susunan, dasar dan tujuan tertentu harus dimiliki setiap Negara. Struktur pemerintahan negara atau forma regimenis berisi tentang konsep negara, susunannya, pembagian kerja antara alat-alat perlengkapannya, yang diciptakan dengan ide para pendiri negara itu. Setiap negara memiliki keunikan dan jati diri yang berbeda-beda, hal ini dikarenakan perbedaan pengalaman mereka sepanjang sejarah yang dilalui. Perbedaan pengalaman sejarah pada akhirnya juga melahirkan ide dan falsafah hidup yang berbeda-beda pulai sesuai dengan perwujudan keinginan dan watak rakyat serta bangsanya. The Founding Fathers bangsa Indonesia telah sepakat menempatkan Pancasila sebagai Filosofische Groundslag yang tertuang di dalam preambule. Sedangkan UUD NRI 1945 adalah Konstitusi Negara Indonesia. Menelaah dalam "Pasal 1 ayat (3)" ditentukan bahwa Negara Indonesia, wujudnya negara hukum. Pendapat tersebut menimbulkan pemikiran bahwa hukum ada karena suatu negara dan konstitusi dijadikan batasan dari penyelenggaraan negara. Proses penyelenggaraaan negara haruslah tunduk kepada hukum yang dibuatnya yakni kepada konsitutif dan peraturan perundang-undangan yang lainnya. Pada dasarnya setiap teks konstitutif yang mengatur kehidupan rakyat memiliki penyakit bawaan (innate defect) maupun penyakit buatan (artificial defect) sebagaimana Henkin juga menyatakan bahwa setiap konstitusi "... reflecting not just the ideas of the time but also the political forces that presided over their birth contributing to the genetic defects."

Sebaik apapun norma yang ada, tetap akan tertinggal oleh perkembangan masyarakat sesuai dengan adagium Belanda yang berbunyi het rechts hink achter de feiten ann (fakta yang ada dikejar oleh hukum yang berjalan tertatih-tatih). ${ }^{9}$ Kendati suatu teks hukum memiliki kecacatan, diharapkan bunyi dan keberlakuan norma dapat fleksibel dan tidak lekang oleh waktu. Terdapat beberapa norma hukum atau ketentuan yang diyakini sebagai identitas dari negara yang sulit untuk dilakukan perubahan terhadapnya atau bahkan dapat dikategorikan sebagai ketentuan yang tidak dapat diubah.

Konsepsi negara kesatuan adalah buah dari kontemplasi dan kesepakatan para pendiri bangsa yang terejawantahkan dalam konstitusi yang menentukan Negara Kesatuan Indonesia berbentuk Republik. Sejak Perubahan pertama hingga perubahan keempat UUD NRI 1945 dengan kurun waktu Tahun 1999-2002 berkaitan bentuk negara menjadi bola panas yang digulirkan dalam proses perubahan UUD 1945, nama hingga akhir, bentuk negara kesatuan ditentukan sebagai klausul yang tidak diperkenankan untuk dirubah (Unamendable Provision) dalam konstitusi.

Memahami keterkaitan antara unamendable provision yaitu bentuk negara kesatuan sebagai salah satu kesepakatan dasar dengan proses perubahaan UUD 1945 haruslah ditinjau dalam kerangka pemikiran teoritik constitution making. Berhubungan dengan pembentukan konstitusi akan terdapat beberapa tujuan yang ingin diraih dalam upaya

\footnotetext{
${ }^{9}$ Zulkarnain Ridlwan, "Negara Hukum Indonesia Kebalikan Nachtwachterstaat," Fiat Justisia: Jurnal Ilmu Hukum 5, no. 2 (March 21, 2011), https://doi.org/10.25041/FIATJUSTISIA.V5NO2.56.
} 
perubahan atas konstitusi tersebut. Dalam hal ini beberapa tujuan itu dapat diuraikan sebagai berikut: 10

a) Melakukan rekonsiliasi terhadap berbagai konflik dalam masyarakat;

b) Memperkuat persatuan nasioanal;

c) Memberdayakan rakyat, dan memberikan ruang partisipasi bagi masyarakat dalam pemerintahan serta menjamin hak asasi manusia;

d) Menyelaraskan nilai-nilai dalam masyarakat dan tujuan nasional;

e) Menyebarluaskan agenda perubahaan UUD NRI 1945;

f) Menegakkan penghormatan atas prinsip-prinsip konstitusionalisme.

Unamendable Provision dalam konstitusi dapat dipahami sebagai semangat untuk memperkuat persatuan nasional menjadi salah satu agenda utama dalam melakukan perubahan atas konstitusi suatu negara. Secara Filosofis terkait keberadaan bentuk negara kesatuan sebagai suatu unamendable provision haruslah dipahami bahwa bentuk negara kesatuan sebagai suatu konsensus besar bangsa dalam mengikatkan identitas dirinya sebagai suatu negara yang didasrkan pada filosofiche groundslag Pancasila terkhusus Sila ke 3 Persatuan Indonesia.

Kerangka pemikiran teoritik yang didasarkan pada pendekatan yuridis atau historical approach dapat ditemukan bahwa sejatinya perdebatan panjang mengenai bentuk negara Indonesia telah terjadi sejak sidang pertama BPUPKI hal ini ditegaskan dengan pidato Muh Yamin dalam sidang BPUPKI secara tegas menyatakan “... Kesejahteraan Rakyat inti dasar negara Indonesia, Merdeka wujudnya keadilan masyarakat atau keadilan sosial. Negara terdiri dari penduduk yang hampir mendekati 100 juta jiwa.11 Jadi paham unitarisme menjadi dasar tersusunnya Republik Indonesia yang merdeka berdaulat.

Dapat ditekankan dan diperjelas bahwa Indonesia ialah negara persatuan yang tidak tercerai-berai, yang tidak terbagi-bagi, dan atas paham unitarisme. Negara yang ideal untuk Negara Indonesia, negara kesatuan (eenheidstaat). Konsepsi Negara Kesatuan yang ditentukan sebagai suatu klausul yang tidak dapat diubah dasar pertimbangannya telah tertuang di dalam naskah komprehensif perubahan UUD NRI 1945 Buku 2 tentang Sendi-Sendi/ Fundamental Negara.

Dialektika yang terjadi dalam pembahasan perubahan bentuk negara pada Masa Perubahan Pertama menitikberatkan kepada perdebatan peserta sidang perubahan UUD NRI 1945 terhadap letak penempatan republik dan kesatuan sebagai suatu bentuk negara. Kerangka teoritik seperti apa yang dapat menjawab amanat pembukaan yang terejawantahkan pada suatu susunan Negara Indonesia yang berbentuk republik namun juga didasarkan pada suatu semangat persatuan nasional. Berkaitan dengan konsepsi bentuk negara Indonesia bahwa yang dimaksud dengan staatform atau bentuk negara kesatuan atau federal sedangkan yang dimaksud dengan regeringfrom atau bentuk pemerintahan merujuk pada bentuk republik.

${ }^{10}$ Ahmad Yani, "Sistem Pemerintahan Indonesia: Pendekatan Teori Dan Praktek Konstitusi Undang-Undang Dasar 1945," Jurnal Ilmiah Kebijakan Hukum 12, no. 2 (2018): 119, https://doi.org/http://dx.doi.org/10.30641/kebijakan.2018.V12.2.

${ }^{11}$ Mujar Ibnu Syarif, "Spirit Piagam Jakarta Dalam Undang-Undang Dasar 1945," Jurnal Cita Hukum 4, no. 1 (June 2, 2016): 15-32, https:// doi.org/10.15408/JCH.V4I1.3568. 
Bilamana konsepsi Negara Kesatuan mengalami perubahan maka secara filosifis dapat dimaknai sebagai upaya pengkhianatan atas segala cucuran keringat, darah, dan pengorbanan jiwa raga seluruh tumpah darah dari sabang sampai merauke yang telah memperjuangkan kemerdekaan Indonesia. Hanya konsepsi Negara Kesatuan adalah bentuk negara yang paling sesuai dengan volkgiest bangsa Indonesia. ${ }^{12}$

Menelisik dalam khazanah sejarah bangsa sejak didirikan hingga Sidang Amandemen UUD 1945 Masa Perubahan Pertama hingga keempat perdebatan bentuk negara kesatuan sebagai konsepsi bentuk negara Indonesia secara filosofis-historis mencapai pada suatu titik temu pemikiran bahwa bentuk negara kesatuan ialah bentuk negara yang didasarkan pada suatu keyakinan sebagai bagian yang tidak dapat dilepasakan dari sejarah pergerakan nasional dalam meraih kemerdekaan.

Secara yuridis normatif dari keberadaan unamendable provision dalam konstitusi tidak dapat dilepaskan dari adanya Panitia Ad Hoc I yang menyusun Kespakatan Dasar ketika proses perubahan UUD NRI 1945. Dalam proses panjang dialektika yang berkaitan dengan keinginan untuk mengubah bentuk Negara Kesatuan terbentur dengan kesadaran akan pentingnya komitmen untuk berpegang teguh atas Kesepakatan Dasar yang telah dibuat sebelumnya. Kesepakatan Dasar menjadi pedoman dalam proses perubahan, sehingga berdasarkan prespektif constitution making tersebut, keberadaan bentuk Negara Kesatuan sebagai unamendable provision dapat dibenarkan dalam kerangka teoritiknya.

Eksistensi MPR dalam konstelasi ketatanegaraan Indonesia haruslah dipahami sebagai suatu Lembaga Negara yang berdiri sendiri. Penafsiran atas frasa "berdiri sendiri" ialah bermakna bahwasannya raison d'etre dari MPR sebagai Lembaga Perwakilan berbeda dengan congress di United State America yang terdiri atas senate dan House of Representative. ${ }^{13}$ Pemahaman ini didasarkan pada tinjauan kewenangan yang berbeda dari yang dimiliki setiap lembaga-lembaga negara di bidang pemerintahan. Adanya perbedaan kewenangan yang dimiliki lembaga yang menjadi wakil rakyat dipemerintahan, maka dapat dikatakan parlemen Indonesia pasca perubahan konstitusi mengenal sistem parlemen trikameral atau triameralisme. Salah satu tuntutan reformasi adalah reformasi konstitusi. Kedudukan lembaga tertinggi negara yang melambangkan kedaulatan mutlak rakyat dirubah menjadi sejajar dengan lembaga negara tinggi lainnya. Keinginan untuk menegakkan negara hukum telah membawa negara Indonesia kedalam pemahamn atas pentingnya suatu amandemen konstitusi. Hal yang menarik pasca dilakukannya amandemen terhadap UUD 1945 yakni pada Perubahan Keempat dengan ditegaskan bahwa "Negara Indonesia pondasinya negara hukum". Hal tersebut memberikan pemaknaan tentang perwujudan Negara Indonesia yang dicerminkan dan diangan-angankan, oleh sebab itulah sudah sepantasnya ada pendalaman mengenai restorasi hukum dan hukum tertulis serta bentukan cita-cita negara hukum. Dalam perkembangannya terdapat problema hukum konstitusi dalam kerangka konstitusionalisme Indonesia meliputi aspek formal/prosedural dan aspek materiil/substansial.

${ }_{12}$ Novendri M Nggilu, "Hukum Dan Teori Konstitusi (Perubahan Konstitusi Yang Partisipatif Dan Populis)" (Yogyakarta: UII Press, 2014).

13 Yash Ghai, "The Role of Constituent Assemblies in Constitution Making," International IDEA. Recuperado El 25 (2006):2008-17. 
Keberadaan ketentuan yang melarang dilakukannya perubahan terhadap bentuk negara kesatuan dapat ditelaah dalam aspek materiil/substansial dalam rangka konstitusionalisme. Dalam aspek materiil/substansial pada awalnya ketentuan "pasal 1 ayat (2) "Kekuasaan di miliki oleh rakyat dan pelaksanaan penuhnya dimiliki oleh MPR". Setelah Perubahan Ketiga menjadi "Kekuasaan ditangan rakyat, pelaksanaanya berdasarkan UUD. Ketentuan baru ini dimaksudkan untuk menegaskan locus kedaulatan rakyat pada supremasi UUD dan bukanlah pada supremasi MPR, yang berarti kekuasaan alat kelengkapan negara terbatas yakni dibatasi UUD.

Keberadaan ketentuan yang tidak dapat diubah dalam konstitusi bilamana ditelaah dalam perspektif identitas konstitusi (constitusional identity) haruslah dipahami sebagai upaya dari sang pembentuk konstitusi untuk melindungi dan menjamin identitas yang melekat pada konstitusi tersebut dari perubahan dengan membatasi kekuatan mengamandemen. Pembentuk konstitusi menyakini bahwasanya isi dari ketentuan tertentu sangat krusial bagi keberadaan konstitusi tersebut sehingga perlu dipertahankan dari generasi ke generasi berikutnya (endured for generation)

Ketentuan yang tidak dapat diubah seperti desain konstitusi yang mampu bekerja melawan tradisi atau kultur dari politik umum negara yang dapat merusak hal fundamental dalam konstitusi sebagaimana pernah dinyatakan oleh Arnold Brecht "...For preventing the posibility the majority rules will abused to authorize barbaric maeasure, it would be advisable for the new constitution contains certains sacrosanct principles and standards which clouds not be impaired even by constitutional amandments". ${ }^{14}$ Hukum sebagai sesuatu yang pasti bermoral dan secara subtansi seperti dewi keadilan yang dapat menyelamtakan rakyat dari ketidakadilan adalah pandangan yang sangat naif, karena pada dasarnya sebuah hukum termasuk amandemen dapat diibaratkan seperti gerobak yang dapat diisikan dengan berbagai kepentingan termasuk hal-hal yang tidak bermoral atau sesuatu yang hanya menguntungkan pihak berkuasa.

Perubahan yang dilakukan terhadap hal-hal fundamental negara dapat membuat tergantikannya seluruh konstitusi atau terciptanya konstitusi baru (complete replacement of the constitution), berdasar kepada hal tersebut penting untuk dipahami bahwa dalam mengamendemen, MPR haruslah melestarikan identitas dan ketahanan konstitusi. Berkaitan dengan pentingnya melestarikan suatu kelestarian identitas dan ketahanan konstitusi dengan memberikan pembatasan terhadap amandemen.

Kewenangan MPR dalam mengubah dan menetapkan konstitusi sebagaimana yang termaktub dalam "Pasal 3 ayat (1)" bukanlah kewenangan untuk membentuk konstitusi baru, kata amandemen (amandment) berarti memperbaiki (correcting) atau menyempurnakan (improving) dan bukan menyusun ulang (reconstruct), menggantikan (replacing), atau bahkan meninggalkan (abandoning) prinsip-prinsip fundamental konstitusi tersebut. Berdasar kepada hal tersebut, segala perubahan harus dianggap tidak berlaku bilamana melanggar esensi kandungan konstitusi.

Keberadaan ketentuan tersebut sejatinya ialah untuk memastikan bahwa MPR dalam menjalankan kewenangannya untuk mengubah konstitusi tidak akan mengubah kefundamentalan konstitusi itu sendiri, bilamana lembaga tertinggi negara melakukan perubahan terhadap hal-hal fundamental seperti bentuk Negara Kesatuan maka

${ }_{14}$ Martha Pigome, "Implementasi Prinsip Demokrasi Dan Nomokrasi Dalam Struktur Ketatanegaraan Ri Pasca Amandemen UUD 1945," Jurnal Dinamika Hukum 11, no. 2 (May 31, 2011): 335-48, https://doi.org/10.20884/1.JDH.2011.11.2.191. 
lembaga tertinggi negara dapat dikatakan telah melakukan penggantian konstitusi dan bukanlah melakukan perubahan kosntitusi. Sementera original intent ketentuan diatas ialah untuk memberikan pembatasan terhadap MPR dalam melakukan perubahan terhadap konstitusi itu sendiri. Berdasar kepada hal-hal tersebut maka keberadaan ketentuan tersebut merupakan bentuk dari supremasi konstitusi yang memberikan pembatasan kepada alat kelengkapan negara dalam hal melakukan perubahan terhadap konstitusi. Hal ini ditunjukkan untuk menegakkan nilai-nilai, hakikat dan tujuan konstitusi itu sendiri.

\subsection{Urgensi Pengaturan Ketentuan tentang Klausul Yang Tidak Dapat Dirubah Dalam Konstitusi}

Pada dasarnya keberadaan klausul yang tidak dapat dirubah dalam praktik ketatanegaraan di dunia bukanlah perkara baru. Gagasan mengenai klausul tersebut telah berkembang dalam konstelasi ketatanegaraan beberapa negara di dunia.

Pendekatan konseptual rumusan suatu klausul yang tidak dapat diubah dalam konstitusi di beberapa negara secara komparasi memang berbeda-beda, meski penggunaan frasa setiap negara tidak sama, namun inti dan tujuan dari klausul itu akan memiliki inti dan tujuan yang sama setiap negara yang memiliki klausul tersebut dalam kehidupan ketatanegaraannya. Keberadaan klausul yang tidak dapat diubah dalam konstitusi diadakan untuk melindungi hal-hal yang bersifat fundamental dari suatu negara sehingga dapat melestarikan dan ketahanan konstitusi suatu negara.

Indonesia yang identitasnya negara hukum, dalam peraturan perundang-undangan juga mengenal adanya suatu hierarki atau jenjang norma. Suatu norma hukum selalu memiliki jenjang norma dalam pemberlakuannya dimana ketentuan peraturan yang kedudukannya lebih tinggi menjadi panduan dasar ketentuan peraturan yang jenjangnya di bawahnya. Pengertian norma hukum tertinggi adalah norma pondasi dasar negara yang tidak terbentuk dari suatu peraturan norma yang lebih tinggi dan menjadi tempat bergantungnya peraturan norma hukum yang lebih rendah.

Pandangan terhadap peraturan norma memiliki hasil pandangan selain norma itu berjenjang, namun juga berkelompok. Terdapat empat kategori besar norma-norma hukum negara yang berlaku yakni Norma Dasar Negara atau Staatfundamentalnorm, Aturan Dasar atau Staatgrundgezetz, Undang-Undang Formal atau Formal gezetz dan aturan pelaksana atau Verordnug satzung. Berdasarkan hal tersebut, maka kosntitusi dapat dikotomikan kedalam dua bagian yakni pembukaan yang berisi nilai-nilai fundamental, filosofi, dan tujuan bernegara sebagai Staatfundamentalnorm dan aturanaturan dasar yang termuat dalam pasal-pasal sebagai Staatgrundgezets. ${ }^{15}$

Letak konstitusi sebagai norma hukum tertinggi dalam peraturan perundangundangan di Indonesia, ditegaskan secara eksplisit dalam Pasal 7 UU Pembentukan Peraturan Perundang-undangan j.o. UU Perubahan atas UU No 12 Tahun 2011, sebagai

${ }^{15}$ Yaniv Roznai, "Unamendability and the Genetic Code of the Constitution," SSRN Electronic Journal, February 24, 2015, https:/ /doi.org/10.2139/SSRN.2569279. 
peraturan negara tertinggi di Indonesia. Asas ini dijadikan landasan dasar atau pijakan untuk para pembentuk peraturan dalam menyusun perundang-undangan. 16

Ada dua klasifikasi dasar pembuatan peraturan undang-undangan yang baik yakni dasar formal dan materiil dimana dasar formil meliputi (1) jelasnya suatu tujuan, (2) organisasi/ kelembagaan yang sesuai, (3) diperlukan pengaturan yang tepat, (4) pelaksanaannya harus sesuai, (5) konsesus. ${ }^{17}$ Sedangkan (i) memiliki terminology dan susunan yang benar, (ii) dapat dipahami, (iii) memiliki kedudukan yang sama di mata hukum, (iv) jelasnya kepastian hukum, (v) keadaan individu yang menjadi dasar pelaksanaannya,semua hal tersebut merupakan dasar materiil yang cukup. Berkaitan dengan urgensitas pengaturan ketentuan itu sendiri dapat ditelaah dengan mendasarkan pada asas tujuan yang jelas dan asas perlunya pengaturan. Keberadaannya bilamana didasarkan pada dasar tujuan yang jelas maka dapat dipahami bahwa tujuan dari perumusan tersebut untuk mengejawantahkan amanat Pembukaaan kosntitusi yaitu melindungi segenap masyarakat Indonesia dan tanah air Indonesia dengan didasarkan kepada berbagai pertimbangan mencakup pertimbangan filisofis, sosio-historis dan yuridis-normatif sebagaimana yang telah diuraikan sebelumnya.

Tujuan dari diadakan ketentuan tersebut untuk memastikan kelestarian Identitas dan Ketahanan UUD 1945 sebagai konstitusi negara Indonesia. Jika ditelaah lebih lanjut dalam kerangka asas perlunya pengaturan dapat dikontruksikan melalui pendekatan sosiologis. Fakta sosiologis Negara Indonesia menunjukkan adanya kemajemukan dalam kehidupan bertatanegara. Hal tersebut merupakan suatu kekayaan bagi negara Indonesia namun bilamana kemajemukan tersebut tidak disikapi dengan bijak tentu dapat menimbulkan suatu ancaman tersendiri.

Bahwa pernah terdapat upaya-upaya yang dilakukan untuk mengubah bentuk negara kesatuan sebagaimana pada masa Konstitusi RIS merubah bentuk negara kesatuan menjadi negara federal namun gejolak yang ada di dalam masyrakat untuk menginginkan dikembalikannya bentuk negara kesatuan, sehingga pada akhirnya bentuk Negara Kesatuan Republik Indonesia didirikan kembali. Melihat kepada halhal tersebut letak penting penempatan bentuk negara kesatuan menjadi pilar berdirinya negara dan sebagai salah satu dari empat tonggak berbangsa dan bernegara harus senantiasa disosialisasikan kepada seluruh rakyat Indonesia semakin jelas adanya. Hal ini sangat diperlukan demi terjaminannya keberlangsungan kehidupan berbangsa dan bernegara Indonesia. Tugas ini merupakan tanggung jawab lembagalembaga negara sesuai amanat yang dimiliki untuk selalu membawa dan mengimplementasi kan ciri khas yang di miliki negara Indonesia, yang sangat majemuk dan dapat menjadi satu dan menerima keanekaragaman tersebut dengan Pancasila sebagai landasan ideologinya dalam bentuk konteks Indonesia negara kesatuan.

Keberadaan klausul yang tidak dapat dirubah dalam konstitusi bilamana ditelaah dalam perspektif identitas konstitusi (constitutional identity) haruslah dipahami sebagai

${ }^{16}$ Yoyon M. Darusman, "Kajian Yuridis Urgensi Amandemen Kelima Undang-Undang Dasar 1945 Dalam Sistem Hukum Ketatanegaraan Indonesia," ADIL: Jurnal Hukum 4, no. 2 (May 16, 2013): 245-65, https://doi.org/10.33476/AJL.V4I2.801.

17 Ferry Irawan Febriansyah, "Konsep Pembentukan Peraturan Perundang-Undangan Di Indonesia," Perspektif 21, no. 3 (September 30, 2016): 220-29, https://doi.org/10.30742/PERSPEKTIF.V21I3.586. 
upaya dari sang pembentuk konstitusi untuk melindungi dan menjamin identitas yang melekat pada konstitusi tersebut dari perubahan dengan membatasi kekuatan. mengamandemen. Pembentuk konstitusi meyakini bahwasannya isi dari ketentuan tertentu tersebut sangat krusial bagi keberadaan konstitusi tersebut sehingga perlu dipertahankan dari generasi ke generasi berikutnya (endured for generation). Klausul yang tidak dapat dirubah seperti sebuah desain konstitusi yang mampu bekerja melawan tradisi atau kultur dari politik umum negara yang dapat merusak hal fundamental dalam konstitusi

\section{Kesimpulan}

Konsepsi bentuk negara kesatuan sebagai klausul yang tidak dapat diubah dalam konstitusi, didasarkan pada penetapan ketentuan pelarangan yang melarang dilakukannya perubahan terhadap bentuk negara kesatuan dalam melakukan perubahan konstitusi. Hal ini terjadi didasarkan kepada pertimbangan filosofis, sosiohistoris dan yuridis normtif. Secara filosofi bentuk negara kesatuan sebagai bagian yang tidak dapat dilepaskan dari Pembukaan konstitusi dan bersifat fundamental. Lebih lanjut secara sosio-historis perubahan terhadap bentuk negara kesatuan pernah terjadi pada Konstitusi RIS 1949 namun pada akhirnya ketidaksesuaian pada jiwa masyarakat terhadap bentuk negara federal mengantarkan kembali bentuk negara kesatuan sebagai suatu yang disepakati bersama. Langkah yuridis normatif ketentuan yang melarang dilakukannya perubahan terhadap bentuk negara kesatuan wujud penegasan kembali atas Dasar Kesepakatan yang telah dibentuk untuk tidak merubah bentuk negara kesatuan ketika melakukan perubahan atas konstitusi. Urgensi ditetapkan ketentuan tersebut dapat ditinjau dalam prespektif berasaskan tujuan yang jelas dan berasaskan perlunya pengaturan. Berdasarkan dua asas tersebut keberadaan kententuan tersebut ditujukan mengejawantahkan amanat melindungi segenap masyarakat Indonesia dan seluruh sendi kehidupan masyarakat Indonesia selain itu klausul yang tidak dapat diubah terhadap konsepsi bentuk negara kesatuan diperlukan untuk menjaga keutuhan wilayah Indonesia. Masyarakat Indonesia yang majemuk sehingga rentan dengan permasalahan intoleransi dan paham radikal yang menginginkan dirubahnya sistem ketatanegaran Indonesia merupakan fakta sosiologis dari klausul yang tidak dapat diubah, terkait konsepsi negara kesatuan di dalam konstitusi menjadi penting dan diperlukan.

\section{Daftar Pustaka}

Buku

Asshiddiqie, Jimly, and M Ali Safa'at. "Hans Kelsen's Theory of Law." Secretariat General and Registrar of the Constitutional Court, Jakarta, 2006.

Martosoewignvo, Sri Soemantri. Procedures and sustems of constitutional changes in the torso of the 1945 Constitution: before and after the amendment of the 1945 Constitution. Alumni, 2006.

Nggilu, Novendri M. "Hukum Dan Teori Konstitusi (Perubahan Konstitusi Yang Partisipatif Dan Populis)." Yogyakarta: UII Press, 2014.

\section{Jurnal}

Darusman, Yoyon M. "Kajian Yuridis Urgensi Amandemen Kelima Undang-Undang Dasar 1945 Dalam Sistem Hukum Ketatanegaraan Indonesia." ADIL: Jurnal 
Hukum 4, no. 2 (May 16, 2013): 245-65. https://doi.org/10.33476/AJL.V4I2.801.

Febriansyah, Ferry Irawan. "Konsep Pembentukan Peraturan Perundang-Undangan Di Indonesia." Perspektif 21, no. 3 (September 30, 2016): 220-29. https://doi.org/10.30742/PERSPEKTIF.V21I3.586.

Ghai, Yash. "The Role of Constituent Assemblies in Constitution Making." International IDEA. Recuperado El 25 (2006): 2008-17.

Pigome, Martha. "Implementasi Prinsip Demokrasi Dan Nomokrasi Dalam Struktur Ketatanegaraan Ri Pasca Amandemen UUD 1945." Jurnal Dinamika Hukum 11, no. 2 (May 31, 2011): 335-48. https://doi.org/10.20884/1.JDH.2011.11.2.191.

Prayitno, Cipto. "Pembatasan Perubahan Bentuk Negara Kesatuan Dalam UndangUndang Dasar 1945 Dalam Perspektif Constitution Making." Jurnal Konstitusi 15, no. 4 (January 15, 2019): 732-51. https://doi.org/10.31078/JK1543.

Ridlwan, Zulkarnain. "Negara Hukum Indonesia Kebalikan Nachtwachterstaat." Fiat Justisia: Jumal Ilmu Hukum 5, no. 2 (March 21, 2011). https://doi.org/10.25041/FIATJUSTISIA.V5NO2.56.

Roznai, Yaniv. "Unamendability and the Genetic Code of the Constitution." SSRN Electronic Journal, February 24, 2015. https://doi.org/10.2139/SSRN.2569279.

Syarif, Mujar Ibnu. "Spirit Piagam Jakarta Dalam Undang-Undang Dasar 1945." Jurnal Cita Hukum 4, no. 1 (June 2, 2016): 15-32. https://doi.org/10.15408/JCH.V4I1.3568.

Tjahjadi, Ivan. “Eksistensi Pasal 37 Ayat (5) Undang-Undang Dasar 1945 Sebagai Larangan Perubahan Pasal Tertentu Dalam Mekanisme Perubahan Konstitusi Dan Hubungannya Dengan Hakikat Konstitusi," 2018. repository.unpar.ac.id/handle/123456789/7414.

Wibowo, Mardian. "Menakar Konstitusionalitas Sebuah Kebijakan Hukum Terbuka Dalam Pengujian Undang-Undang." Jurnal Konstitusi 12, no. 2 (May 20, 2016): 196-216. https://doi.org/10.31078/JK1221.

Yani, Ahmad. "Sistem Pemerintahan Indonesia: Pendekatan Teori Dan Praktek Konstitusi Undang-Undang Dasar 1945." Jurnal Ilmiah Kebijakan Hukum 12, no. 2 (2018): 119. https://doi.org/http://dx.doi.org/10.30641/kebijakan.2018.V12.2

Yusa, I Gede, and Bagus Hermanto. "Implementasi Green Constitution Di Indonesia: Jaminan Hak Konstitusional Pembangunan Lingkungan Hidup Berkelanjutan." Jurnal Konstitusi 15, no. 2 (September 18, 2018): 306-26. https: //doi.org/10.31078/JK1524.

\section{Tesis / Disertasi}

Salim, Agus, Agus Ngadino, and Vegitya Ramadhani Putri. “Keberadaan Klausul Yang Tidak Dapat Diubah (Unamendable Provision) Dalam Undang-Undang Dasar Negara Republik Indonesia Tahun 1945," March 18, 2018.

Satrio, Abdurrachman. "Klausul Larangan Mengubah Bentuk Negara Kesatuan Republik Indonesia Dalam Undang-Undang Dasar 1945: Perspektif Identitas Konstitusi," 2018. http://repository.unpad.ac.id/frontdoor/index/index/docId/1811.

\section{Peraturan Perundang-Undangan}

Undang-Undang Dasar Negara Republik Indonesia 1945

Undang- Undang Nomor 12 Tahun 2011 tentang Pembentukan Peraturan Perundangundangan 
P-ISSN:2302-528X, E-ISSN: 2502-3101

Undang-Undang Nomor 15 Tahun 2019 tentang Perubahan atas Undang-Undang Nomor 12 Tahun 2011 